\title{
Interactions of Porphyrin-Acridine Hybrids to DNA Duplexes and Quadruplex: In Silico Study
}

\author{
Hubbi Nashrullah Muhammad*, Sophi Damayanti, Daryono H. Tjahjono \\ School of Pharmacy, Bandung Institute of Technology, Jalan Ganesha 10, Bandung 40132, Indonesia.
}

Received: 18 September, 2014 / Accepted: 30 November 2014

\begin{abstract}
:
The binding modes of cationic porphyrin hybrids to DNA has been studied in a previous study. In the present research, cationic porphyrinacridine hybrids bearing meso-substituted pyridine, imidazole, and pyrazole rings were investigated for their interaction with DNA. AutoDock Vina was used to dock 11 compounds to four different DNA duplexes, dodecamers d(CGCAAATTTGCG)2 (PDB code: 102D) and d(CGCGAATTCGCG)2 (PDB code: 1PRP), and hexamers d(CGATCG)2 (PDB code: 1Z3F) and d(TGATCA)2 (PDB code: 182D), as well as a human telomeric DNA quadruplex (PDB code: $1 \mathrm{KF} 1$ ). The binding mode and affinity of each compound were then compared to that of meso-tetrakis(4-methylpyridiniumyl)porphyrin (TMPyP). The hybrid compounds interacted with the DNA duplexes through intercalation and groove binding, while the interaction with DNA quadruplex was strictly stacking. Porphyrin-acridine hybrids with two meso-substituted diazolium rings exhibited higher affinity towards both DNA duplex and quadruplex than that of mono- and tri-substituted derivatives. Bis- $\mathrm{H}_{2} \mathrm{PyP}-2 \mathrm{AC}$ resulted in the highest affinity towards DNAs representing minor groove binding, with binding free energies of -12.3 and $-13.8 \mathrm{kcal} / \mathrm{mol}$ towards $102 \mathrm{D}$ and $1 \mathrm{PRP}$, respectively, and bis- $\mathrm{H}_{2} \mathrm{ImP}-2 \mathrm{AC}$ docked well with quadruplex DNA $1 \mathrm{KF} 1 \mathrm{with}$ a binding free energy of $-11.6 \mathrm{kcal} / \mathrm{mol}$.
\end{abstract}

Key words: DNA-porphyrin, docking, groove binding, intercalation, porphyrin hybrids

\section{Introduction}

Cationic porphyrins have attracted a great deal of interest since its discovery by Fiel et. al. [2] and many studies have been carried out that focused on understanding their non-covalent interactions with DNA. Aside from interacting strongly with DNA, cationic porphyrins can also cleave DNA [3], have high photonuclease and photodynamic therapy (PDT) activities [4], and have been found to inhibit telomerase through G-quadruplex stabilisation [5]. Through studies of porphyrin interactions with DNA, three distinct binding modes have been proposed for the DNA binding of porphyrins: intercalation, outside groove binding, and outside binding with self-stacking. Several factors have been identified that play an important role in the binding of porphyrins to DNA, such as ionic strength, the presence and nature of metal ions complexed in the porphyrin core, and the type and position of substituents on the porphyrin ring $[6,7]$.

Various meso-substituted porphyrins, such as mesotetrakis-(N-methylpyridinium-4-yl)porphyrin (TMPyP) are well known as cationic porphyrins that interact strongly with DNA [8,9]. Recently, cationic porphyrins bearing five-membered rings at the meso-position, mesotetrakis (1,3-dimethylimidazolium-2-yl) porphyrin $\left(\mathrm{H}_{2} \mathrm{ImP}\right)$ and meso-tetrakis-(1,2-dimethyl-pyrazolium-4yl) porphyrin $\left(\mathrm{H}_{2} \mathrm{PzP}\right)$, and their metal complex derivatives, have been synthesized and was found to increase porphyrin binding to DNA [10]. Other efforts to

\footnotetext{
*Corresponding author: Hubbi Nashrullah Muhammad,

E-mail: hubbinash@students.itb.ac.id
}

increase the affinity and activity of porphyrins to DNA include the addition of certain chemical groups at the meso-20-position of the porphyrin ring forming hybrid compounds. One such chemical compound that show promising properties and activities when conjugated to certain porphyrins is acridine [11], an antibacterial compound that is known as a good DNA intercalator [12]. However, the mechanisms of porphyrin-acridine hybrid binding to DNA has yet to be fully understood. The present study aims to investigate the interactions of porphyrin hybrids bearing meso-substituted pyridine, imidazole, and pyrazole rings to DNA duplexes and quadruplex using molecular docking techniques. ratio [6].

\section{Experimental}

\section{Macromolecul preparation}

Crystal structures of the DNA duplexes and quadruplex were downloaded from the Protein Data Bank. PDB structures with codes 102D and 1PRP for the dodecamers d(CGCAAATTTGCG $)_{2}$ and d(CGCGAATTCGCG $)_{2}$, respectively, were used to analyse minor groove binding to DNA duplexes, while structures with $\mathrm{PDB}$ codes $1 \mathrm{Z3F}$ and $182 \mathrm{D}$ for the hexamers d(CGATCG $)_{2}$ and d(TGATCA $)_{2}$, respectively, serve as intercalative binding models to DNA duplexes. A human telomeric DNA quadruplex with PDB code $1 \mathrm{KF} 1$ was also used. 


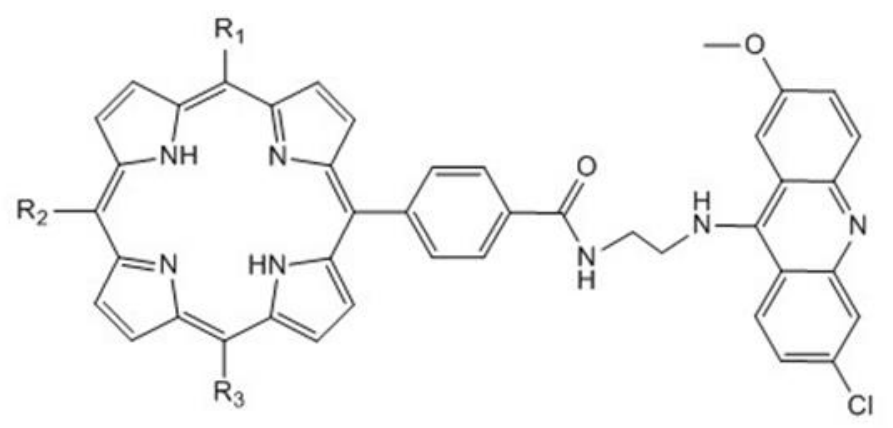

$\mathrm{H}_{2} \mathrm{P}-2 \mathrm{AC} \quad \mathrm{R}_{1}=\mathrm{R}_{2}=\mathrm{R}_{3}=\mathrm{H}$

mono- $\mathrm{H}_{2} \mathrm{ImP}-2 \mathrm{AC} \quad \mathrm{R}_{1}=\mathrm{R}_{3}=\mathrm{H} \quad \mathrm{R}_{2}=\mathrm{N}^{+}$

bis- $\mathrm{H}_{2} \mathrm{PyP}-2 \mathrm{AC} \quad \mathrm{R}_{2}=\mathrm{H} \quad \mathrm{R}_{1}=\mathrm{R}_{3}=$

bis- $\mathrm{H}_{2} \mathrm{PzP}-2 \mathrm{AC}$

$\mathrm{R}_{2}=\mathrm{H} \quad \mathrm{R}_{1}=\mathrm{R}_{3}=$

tris- $\mathrm{H}_{2} \operatorname{ImP}-2 \mathrm{AC} \quad \mathrm{R}_{1}=\mathrm{R}_{2}=\mathrm{R}_{3}=\mathrm{N}^{-}$ mono- $\mathrm{H}_{2} \mathrm{PyP}-2 \mathrm{AC} \quad \mathrm{R}_{1}=\mathrm{R}_{3}=\mathrm{H} \quad \mathrm{R}_{2}=$

mono- $\mathrm{H}_{2} \mathrm{PzP}-2 \mathrm{AC} \quad \mathrm{R}_{1}=\mathrm{R}_{3}=\mathrm{H} \quad \mathrm{R}_{2}=\prod_{N-N}$

bis- $\mathrm{H}_{2} \mathrm{ImP}-2 \mathrm{AC}$

$\mathrm{R}_{2}=\mathrm{H} \quad \mathrm{R}_{1}=\mathrm{R}_{3}=\mathrm{N}^{\mathrm{N}^{+}}$

tris- $\mathrm{H}_{2} \mathrm{PyP}-2 \mathrm{AC}$

$\mathrm{R}_{1}=\mathrm{R}_{2}=\mathrm{R}_{3}=$

tris- $\mathrm{H}_{2} \mathrm{PzP}-2 \mathrm{AC}$

Figure 1. Structure of the porphyrin-acridine hybrids used in this study.

\section{Ligand preparation}

Eleven porphyrin-acridine hybrid compounds were constructed using the GaussView software (Figure 1). Geometry optimization was performed on the Gaussian09 software using the density functional theory (DFT) method with the Beck three-parameter Lee-YangParr (B3LYP) function and the $6-31 \mathrm{G}^{*}$ basis set. The lowest energy conformation of each ligand was selected and used in the subsequent docking study.

\section{Molecular docking}

Autodock Tools 1.5.6 was used to prepare the ligands and macromolecules for the docking study. The DNA receptors were added polar hydrogens and the ligands were prepared with maximum torsion. Autodock Vina 1.1.2 was then used to dock the 11 compounds to four DNA duplexes and a DNA quadruplex using a grid box with a size of $20 \times 20 \times 20 \AA$ at the minor groove or intercalation binding site.

\section{Results and Discussion}

The lowest energy conformations of tris- $\mathrm{H}_{2} \mathrm{PyP}-2 \mathrm{AC}$, tris- $\mathrm{H}_{2} \mathrm{ImP}-2 \mathrm{AC}$, and tris- $\mathrm{H}_{2} \mathrm{PzP}-2 \mathrm{AC}$ are shown in Figure 2. All ligand conformations had similar geometries; the acridine groups were perpendicular to the porphyrin ring. The long chain connecting the porphyrin ring to the acridine group allow it to form a more stable conformation and contribute to the hybrid molecule's interaction with DNA.
Docking simulations revealed that porphyrin-acridine hybrid compounds can interact with DNA duplexes via minor groove and intercalative binding. The docking score of each of the ligands on the DNA receptors are shown in Table 1 . The results show that bis- $\mathrm{H}_{2} \mathrm{PyP}-2 \mathrm{AC}$ is best docked on DNA duplexes that represent minor groove binding, 102D and 1PRP, with binding free energies of -12.8 and $-11.2 \mathrm{kcal} / \mathrm{mol}$, respectively. Both complexes indicate that the interaction is stabilised by the porphyrin ring binding to the DNA through the minor groove, further assisted by the acridine group. The long chain connecting the porphyrin ring and the acridine moiety allows the hybrid molecule to easily adhere to the curved groove of the DNA duplex. However, the complex formed between bis- $\mathrm{H}_{2} \mathrm{PyP}-2 \mathrm{AC}$ and $102 \mathrm{D}$ was in a more stable conformation compared to that of 1PRP, with a binding energy difference of 1.6 $\mathrm{kcal} / \mathrm{mol}$. In addition, bis- $\mathrm{H}_{2} \mathrm{PyP}-2 \mathrm{AC}$ also exhibited a good interaction with the intercalative binding DNA model $1 \mathrm{Z} 3 \mathrm{~F}$ with a binding energy of $-10.0 \mathrm{kcal} / \mathrm{mol}$. This docking score is only $0.6 \mathrm{kcal} / \mathrm{mol}$ lower than that of the ligand with the best conformation at $1 \mathrm{Z} 3 \mathrm{~F}$, namely mono- $\mathrm{H}_{2}$ PyP-2AC, with a binding score of -10.6 $\mathrm{kcal} / \mathrm{mol}$.

Porphyrin-acridine hybrids with one (mono-) and two (bis-) meso-substituents intercalate well into $1 \mathrm{Z3F}$ due to strong $\pi-\pi$ interactions between the planar and hydrophobic porphyrin ring and the DNA base pairs, while the acridine group contribute to the interaction by stacking on the minor groove (Figure 3). However, these ligands did not intercalate into $182 \mathrm{D}$, but rather 
interacted through minor groove binding (Figure 4). This may suggest that porphyrin-acridine hybrids prefer intercalating into the CG-rich regions of DNA rather than the AT-rich regions. Additionally, hybrid molecules with three (tris-) meso-substituents do not intercalate well into DNA duplexes, most probably due to steric hindrance.

In general, porphyrin-acridine hybrids tend to prefer binding with DNA duplexes through the minor groove than through intercalation, evidenced by the lower binding energies of the complexes with 102D and 1PRP compared to those of $1 \mathrm{Z3F}$ and $182 \mathrm{D}$. This may be due to the fact that the room available for intercalation is smaller and the hybrid molecules are constrained by their peripheral substituents. The role of steric hindrance in the interaction with DNA is further illustrated by the low affinities (higher binding energies) of tris compounds to all duplexes.

Docking of the ligands to $102 \mathrm{D}$ resulted in lower binding energies than to 1PRP, which suggests that porphyrin- acridine hybrids prefer the AT-rich regions of DNA when binding to the minor groove. This is also supported by the fact that the ligands interacted with the AT-rich $182 \mathrm{D}$ duplex through minor groove binding rather than intercalation, and has also been demonstrated by previous research [13]. On the other hand, docking to $1 \mathrm{Z3F}$ resulted in relatively stable complexes, which shows that the hybrid molecules prefer CG-rich regions of DNA for intercalation.

Interactions of porphyrin - acridine hybrids with quadruplex DNA differs from those with DNA duplexes; the hybrid compounds binds to DNA quadruplex strictly through stacking on the outer layer of the guanine tetrads (Figure 5). Unlike minor groove binding and intercalation, the acridine moiety did not seem to play a role in this stacking interaction; docking of all mesosubstituted porphyrin-acridine hybrids to $1 \mathrm{KF} 1$ resulted in similar binding affinities, despite the acridine group being in different positions.
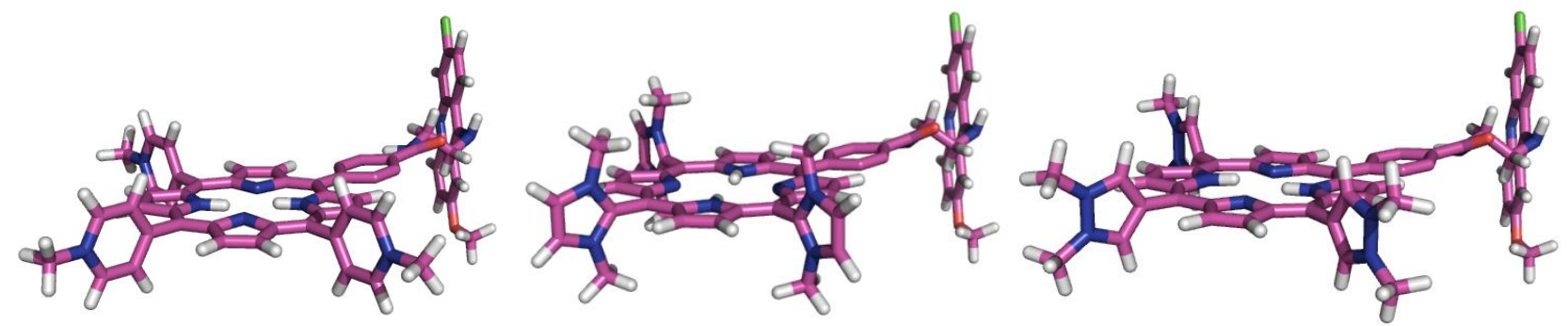

Figure 2. Optimized geometries of tris- $\mathrm{H}_{2} \mathrm{PyP}-2 \mathrm{AC}$ (left), tris- $\mathrm{H}_{2} \mathrm{ImP}-2 \mathrm{AC}$ (center) and tris- $\mathrm{H}_{2} \mathrm{PzP}-2 \mathrm{AC}$ (right).

Table 1. Binding free energies of porphyrin-acridine hybrids to DNA duplexes and quadruplex

\begin{tabular}{|c|c|c|c|c|c|}
\hline \multirow{2}{*}{ Ligand } & \multicolumn{5}{|c|}{ Binding energy $(\mathrm{kcal} / \mathrm{mol})$} \\
\hline & 102D & $1 \mathrm{PRP}$ & $1 \mathrm{Z3F}$ & $182 \mathrm{D}$ & $1 \mathrm{KF} 1$ \\
\hline TMPyP & -4.9 & -5.5 & -3.3 & -6.4 & -7.1 \\
\hline $\mathrm{H}_{2} \mathrm{P}-2 \mathrm{AC}$ & -11.0 & -9.2 & -9.1 & -8.3 & -10.2 \\
\hline mono- $\mathrm{H}_{2} \mathrm{PyP}-2 \mathrm{AC}$ & -10.5 & -10.2 & -10.6 & -10.0 & -8.1 \\
\hline mono- $\mathrm{H}_{2} \mathrm{ImP}-2 \mathrm{AC}$ & -10.5 & -10.3 & -10.3 & -9.7 & -8.3 \\
\hline mono- $\mathrm{H}_{2} \mathrm{PzP}-2 \mathrm{AC}$ & -10.4 & -10.3 & -9.9 & -9.9 & -8.2 \\
\hline bis- $\mathrm{H}_{2} \mathrm{PyP}-2 \mathrm{AC}$ & -12.8 & -11.2 & -10.0 & -8.1 & -9.4 \\
\hline bis- $\mathrm{H}_{2} \operatorname{ImP}-2 \mathrm{AC}$ & -10.6 & -10.1 & -9.5 & -9.3 & -9.2 \\
\hline bis- $\mathrm{H}_{2} \mathrm{PzP}-2 \mathrm{AC}$ & $-9,7$ & -11.1 & -9.4 & -8.5 & -8.1 \\
\hline tris- $\mathrm{H}_{2} \mathrm{PyP}-2 \mathrm{AC}$ & -5.7 & -7.0 & -4.3 & -6.4 & -8.4 \\
\hline tris- $\mathrm{H}_{2} \mathrm{ImP}-2 \mathrm{AC}$ & -4.7 & -6.6 & -6.3 & -5.9 & -9.0 \\
\hline tris- $\mathrm{H}_{2} \mathrm{PzP}-2 \mathrm{AC}$ & -5.2 & -6.2 & -5.9 & -7.4 & -9.8 \\
\hline
\end{tabular}




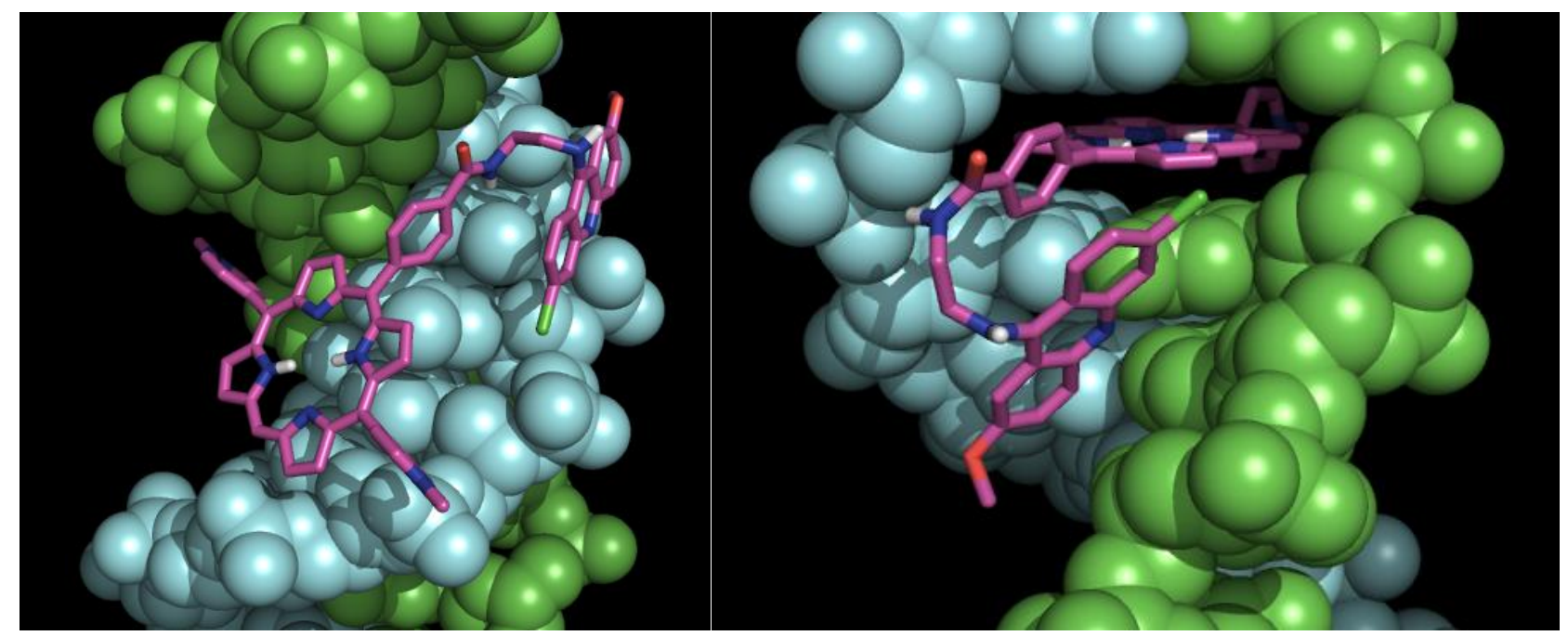

Figure 3. Binding modes of bis- $\mathrm{H}_{2} \mathrm{PyP}-2 \mathrm{AC}$ to $102 \mathrm{D}$, binding energy $=-12.8 \mathrm{kcal} / \mathrm{mol}$ (left), and mono- $\mathrm{H}_{2} \mathrm{PyP}-2 \mathrm{AC}$ to $1 \mathrm{Z3F}$, binding energy $=-10.6 \mathrm{kcal} / \mathrm{mol}$ (right).

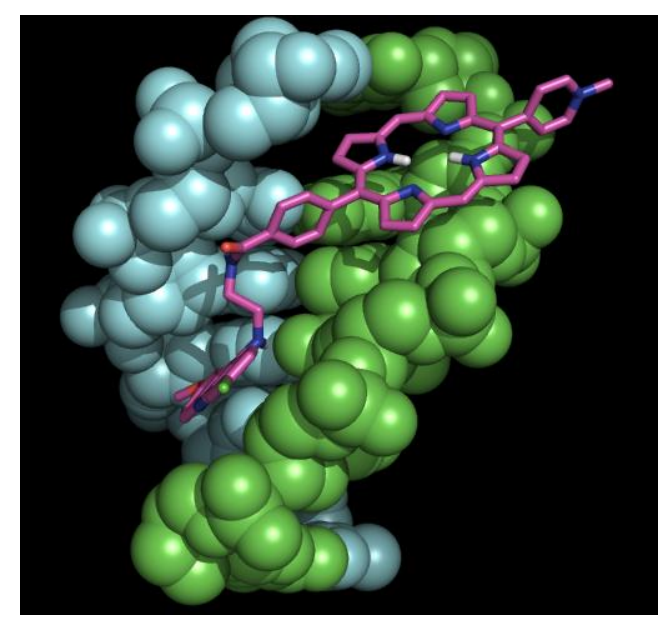

Figure 4. Conformation of mono- $\mathrm{H}_{2} \mathrm{PyP}-2 \mathrm{AC}$ to the minor groove of $182 \mathrm{D}$.

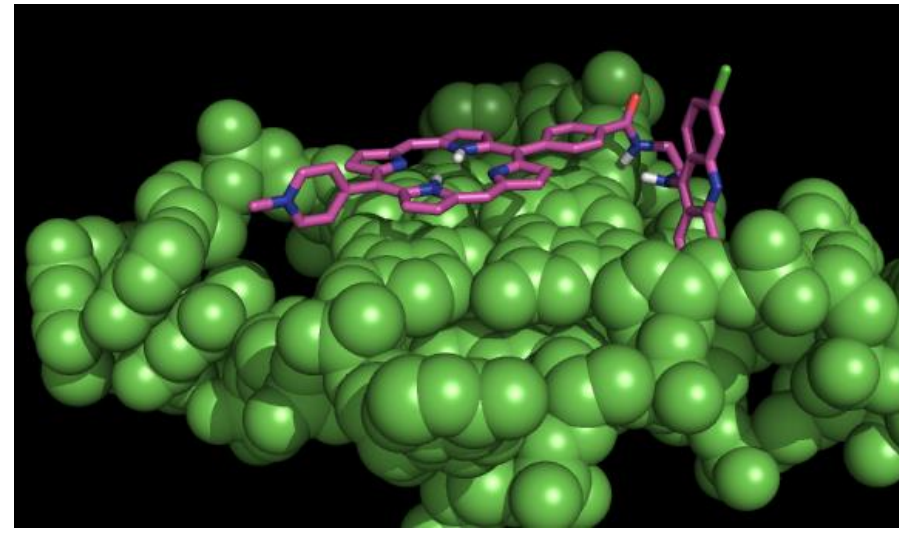

Figure 5. Stacking of mono- $\mathrm{H}_{2} \mathrm{PyP}-2 \mathrm{AC}$ on the guanine tetrads of quadruplex DNA $1 \mathrm{KF} 1$.

\section{Conclusions}

Cationic porphyrin-acridine hybrids interact with DNA duplexes through minor groove and intercalative binding, and with DNA quadruplex through stacking on the guanine tetrads. Minor groove binding prefers the ATrich regions of DNA while intercalation prefers the CGrich regions. The acridine moiety of the hybrid molecules assist the interaction to DNA duplexes by binding to the minor groove. However, it does not appear to play a part in the interaction with DNA quadruplex.

\section{Acknowledgement}

HNM thanks Directorate General of Higher Education for PMDSU scholarship.

\section{References}

[1] Fiel, R.J., Howard, J.C., Mark, E.H., Datta-Gupta, N., Nucleic Acids Res., 6, 1979, 3093-3118.

[2] Pratviel, G., Bernadou, J., Meunier, B., Met. Ions Biol. Syst., 33, 1996, 399-426.

[3] MacDonald, I.J., Dougherty, T.J., J. Porphyrins Phthalocyanines, 5, 2001, 105-129.

[4] Yamamoto, T., Tjahjono, D.H., Yoshioka, N., Inoue, H., Bull. Chem. Soc. Jpn., 76, 2003, 1947-1955.

[5] Pasternack, R.F., Gibbs, E.J., Met. Ions. Biol. Syst., 33, 1996, 367-397.

[6] Dixon, D.W., Steullet, V., J. Inorg. Biochem., 69, 1998, 25-32.

[7] Wheelhouse, R.T., Sun, D., Han, H., Han, F.X., Hurley, L.H., J. Am. Chem. Soc., 120, 1998, 32613262.

[8] Han, F.X., Wheelhouse, R.T., Hurley, L.H., J. Am. Chem. Soc., 121, 1999, 3561-3570. 
[9] Tjahjono, D.H., Akutsu, T., Yoshioka, N., Inoue, H., Biochim. Biophys. Acta, 1472, 1999, 333-343.

[10] Ishikawa, Y., Yamashita, A., Uno, T., Chem. Pharm. Bull., 49, 2001, 287-293.
[11] Lerman, L.S., Proceedings of the National Academy of Sciences, 1963, 94-102.

[12] Pasternack, R.F., Gibbs, E.J., Villafranca, J.J., Biochemistry, 22, 1983, 2406-2414. 